As regards the expression sva-mänèna, it stands to reason that the measures must be taken according to an angula or a cubit which is of a fixed standard length; not according to the varying finger-breadths and cubits of individuals who are to be measured, as seems to be suggested by the Tibetan text, or by the translation of it.

Verse 107 tells us that the measure should be taken at the age of 25 years. And Bhattōtpala says, in his commentary under verse 105 , that it is to be made for a man standing upright, "from the junction of the ground and the feet to the middle of the head : i.e. from the soles of his feet to the crown of his head, just as is shown in the drawing from Lhasa at p. 1244.

J. F. FLEET.

\title{
Early Use of the Buddhist Era in Burma
}

I have no thesis of my own to maintain, and should not venture to say more on this matter if I did not hope that the discussion of it would elicit new facts. I merely entered a respectful caveat against Dr. Fleet's conclusion, founded on Ceylonese evidence, which appears to be of a negative character for the period prior to A.D. 1165 . It was precisely because Dr. Fleet had not distinguished the issues involved that I thought it necessary, for the sake of clearness, to do so. It is no wish of mine to trouble him with the details of Burmese chronology, which is no more my subject than his. But the issues, though distinct, are more or less interdependent. In a discussion on the origin of the Buddhist era any apparent use of a similar reckoning in any Buddhist country is material evidence. Non constat, at present, that the reckoning was not invented in Burma and transported thence to Ceylon, modified there, and subsequently reimported into Burma. ( $\mathrm{I}$ hasten to add that $\mathrm{I}$ am not putting this forward as a proposition to be argued.) $\mathrm{My}$

JRAS. 1911. 
point is that the Talaing and Burmese evidence is entitled to as much consideration as the Ceylonese.

Dr. Fleet does not appear to take that view. From the fact that no Ceylonese records have been found giving instances of the use of the Buddhist era (revised reckoning) before circa A.D. 1165, he is ready to infer that it was invented about that time. But when one quotes IndoChinese inscriptions bearing (or appearing to bear) against that conclusion, he brushes them aside as being probably not synchronous documents, and objects to the arguments by which they are supported as being "hypothetical". When definite evidence is wanting, the use of hypothesis is inevitable. Dr. Fleet's hypothesis is that the three inscriptions $I$ have cited are all of some date later than A.D. 1170-80 (Buddhist reckoning 1713-23), although their sole purport is to discuss certain particular events and circumstances connected with a king, or kings, associated with the Buddhist date 1628 or 1630 . I submit that in the overwhelming majority of cases inscriptions, and especially bulky records on stone pillars, are put up soon after the events which they are erected to record: if people do not think it worth while to record them at once, much less are they likely to do so half a century or more afterwards. Should we at this present time be inclined to set up inscriptions giving a full and particular account of the events connected with the death of King William IV?

I submit that Dr. Fleet's hypothesis is far more improbable than mine. As two of the inscriptions do not mention their own dates and $I$ am not yet prepared to deal in detail with the longer one, I cannot put the case higher than that. As regards the third, I regret exceedingly that owing to its present dilapidated condition the date on which it claims to have been made is doubtful, and must perhaps remain so. But as Dr. Fleet has put certain questions on it, I will do my best to answer them. 
It is possible that the draftsman misspelt the name of the nakșatra, but its initial is certainly $p h$, not $b h$. The two letters bear no resemblance to one another in this script. 'The modern Talaings do not use Indian names for the two lunar fortnights, but have terms of their own. Probably the Talaings of the twelfth century also used these. It so happens that (in the modern language) both the words in question end in $-k$. Dr. Fleet's discussion about the Indian names seems, therefore, hardly in point. I have already given reasons why I consider it quite out of the question that this record could have been put up in any century later than the twelfth. And what other date than the one suggested will fit the particulars that have been preserved? In any case this Shwesandaw inscription relates to the same matters as the Shwezigon one. If it is long odds against either of them having been put up when those matters had ceased to be of practical interest, the odds against the double event are ever so much longer, I should imagine.

Burmese inscriptions are quite beyond me, and I must leave them to be dealt with by some one who knows Burmese. But I have been at some pains to go through the published untranslated collections of inscriptions from Upper Burma and Bodawpaya's Mandalay Inscriptions with a Burman, and I find several cases of the use of the Buddhist era apparently before A.D. 1165. Most of these appear to be from copies made by the order of King Bodawpaya. But as the originals are no longer available, and there seems to be no particular reason for suspecting that the dates have been altered, they seem to be as good evidence as we are likely to get. Until they have been critically examined, I cannot venture to say very much more about the use of the Buddhist reckoning in Burma in early times. Whether it is connected in any way with the Ceylonese reckoning is a further point on which it may be advisable for the present to suspend 
judgment. I suspect that variations in the initial point of the Buddhist era are responsible for many of the discrepancies in early Burmese chronology of which Dr. Fleet justly complains. That is another reason why, in my judgment, all this evidence, Talaing and Burmese as well as Ceylonese, will have to be considered together before any final conclusions can be arrived at.

\section{O. Blagnen.}

In this Journal, 1910 , pp. $474-81$ and pp. $850-60$, is an interesting discussion on "The Revised Buddhist Era in Burma", carried on between Dr. Fleet and Mr. Blagden, and the latter has asked me to intervene. Most willingly do I comply with his request.

The thesis laid down by Dr. Fleet and questioned by Mr. Blagden is this:- That the reckoning with the initial point in B.C. 544 was devised in Ceylon, was put together in its complete form just after A.D. 1165, and was carried to Burma in the decade A.D. 1170-80.

At pp. 256-7 of the Indian Antiquary, vol. xxiii, 1894, I have discussed about the Burmese eras and the mode of reckoning them. There are three eras, namely, the Era of Religion, which began in B.c. 544; the Saka Era, which began in A.D. 78 ; and the Chinese Era, now current, which began in A.D. 638 . The Saka Era was established in its own second year, after wiping out $622(544+78=$ Dodorasa) years of the Era of Religion; and the Chinese Era was established after wiping out 560 (Khachhapañcha) years of the Saka Era.

There appears to be strong evidence to show that the Era of Religion or the Nirvanna Era, which began in B.C. 544, was known to the Burmans long before the twelfth century A.D. When they adopted the Saka as well as the Chinese Era, the year was reckoned in its equivalent of Anno Buddhæ. Further, at pp. 49-50 of the Kalyannị 